\title{
The effect of cell wall degrading enzymes on the preservation of grass and on the silage intake and digestibility in sheep
}

\author{
SEIJA JAAKKOLA \\ Department of Animal Husbandry, University of Helsinki, \\ SF-00710 Helsinki, Finland
}

\begin{abstract}
Two experiments were carried out to study the effects of cell wall degrading enzymes as silage additive. A primary growth of timothy was cut with a mower and picked up with a precision-chop forage harvester in Exp. I (early cut), and harvested as direct-cut with a precision-chop harvester in Exp. II (late cut). The additive treatments were in Exp. I: 1) unwilted formic acid (FA) applied as AIV II (4.5 l/t), 2) wilted untreated, 3) wilted FA (4 l/t), 4) wilted enzyme A (glucose oxidase (GO) + hemicellulase (HC) $150 \mathrm{ml} / \mathrm{t}+$ cellulase (C) $200 \mathrm{ml} / \mathrm{t}$ ), 5) wilted enzyme B (HC $150 \mathrm{ml} / \mathrm{t}+\mathrm{C} 200 \mathrm{ml} / \mathrm{t})$; and in Exp. II: 1) untreated, 2) FA (4 1/t), 3) $\mathrm{E} 200(\mathrm{C} 200 \mathrm{ml} / \mathrm{t}+\mathrm{GO})$, 4) $\mathrm{E} 400$ (C $400 \mathrm{ml} / \mathrm{t}+\mathrm{GO})$, 5) $\mathrm{E} 800$ (C $800 \mathrm{ml} / \mathrm{t}+\mathrm{GO})$. The rate of application of $\mathrm{GO}$ was $50000 \mathrm{IU} / \mathrm{t}$. The silages were ensiled in pilot scale silos $\left(3 \mathrm{~m}^{3}\right)$ and the voluntary intake and digestibility in sheep were determined in two experiments designed as a $5 \times 5$ Latin square.

The use of enzymes decreased the fibre content of silages, mainly the cellulose fraction, as compared with FA and untreated silages. Enzyme silages were well preserved with a low $\mathrm{pH}(3.93-4.15)$, moderate ammonia $\mathrm{N}(72-119 \mathrm{~g} / \mathrm{kg}$ total $\mathrm{N})$ and no butyric acid. As compared with untreated silages (mean $\mathrm{pH} 4.6$, ammonia $\mathrm{N} \mathrm{131}$ ) the preservation was improved. The FA silages were also well preserved ( $\mathrm{pH} 4.0$, ammonia $\mathrm{N} \mathrm{57)}$ with more restricted fermentation than enzyme silages. FA and especially higher levels of enzymes increased the amount of effluent. In Exp. I, the digestibilities of dry matter (DM), organic matter (OM) and crude fibre were not significantly $(\mathrm{P}>0.05)$ affected by the silage treatment. In Exp. II, the digestibility of DM and OM decreased linearly $(\mathrm{P}<0.05)$ with the increasing level of enzyme application. The digestibility of NDF and ADF was higher with untreated than with other silages, higher with FA than enzyme silages and decreased linearly with the increasing level of enzymes $(\mathrm{P}<0.01)$.
\end{abstract}

Index words: grass silage, additives, enzymes, preservation, digestibility 


\section{Introduction}

The preservation of high moisture grass by ensiling is based on a reduced $\mathrm{pH}$ under anaerobic conditions. A high hydrogen ion concentration prevents the adverse effects of microbes and plant enzymes. Together with anaerobiosis, an adequate supply of fermentable substrates, mainly water soluble carbohydrates (WSC) of grass, is a major prerequisite for the preservation without additive. With acid additives the hydrogen ion concentration is increased by an extraneous addition and the natural fermentation is partly inhibited. In addition to acidification, a selective bactericidal action of the undissociated acid may improve the preservation (WoolFORD 1975). Formic acid has long been known to be an efficient additive (e.g. SAUE and Breirem 1969, Wilson and Wilkins 1973). However, it is unpleasant if no hazardous to handle. To avoid these problems while achieving good preservation, bacterial inoculants have been studied as additive to stimulate the fermentation, and enzymes to increase the amount of substrate for fermentation by degrading plant cell walls (e.g. OLsON and Voelker 1961, Hendersson et al. 1982, JACOBS and McAllan 1987). It has also been argued that the use of enzymes increases silage intake and animal performance by enhancing the rate and/or exient of breakdown of plant structural carbohydrates in the rumen.

Results from the use of bacterial inoculants have been inconsistent (Done 1986). SEALE et al. (1986) concluded that inoculants can quickly utilize available and supplied WSC in the forage, but they cannot work successfully to achieve satisfactory fermentation if WSC is a limiting factor. The use of cellulolytic enzymes has been found to reduce the cellulose content (McGullough 1964, Autrey et al. 1975, Hendersson and McDonald 1977) and the pH (Autrey et al. 1975, Hendersson and McDonald 1977) of different kinds of silages as compared with untreated silages. When comparing untreated silages with enzyme silages, no differences were observed in the digestibility of sorghum (OWEN 1962) or alfalfa haylage (JASTER and MORE 1988). Some indication of improved digestibility of maize silage (Autrey et al. (1975) and sorghum (McCullough 1964) after cellulase treatment has been reported. However, the data concerning the ability of enzymes to preserve low moisture grass or improve digestibility are still inadequate.

The purpose of the present experiments was to study the effects of enzymes (cellulase, hemicellulase, glucose oxidase) and formic acid as grass silage additives on the fermentation quality, digestibility and voluntary intake in sheep. In addition, it was studied whether the adverse effects of postponed harvesting on the digestibility of silage could be eliminated by the use of enzymes. Preliminary results have been reported by HUHTANEN et al. (1985).

\section{Materials and methods}

\section{Silages}

\section{Experiment I}

A primary growth of leaf stage timothy (Phleum pratense) sward was cut with a mower and collected with a precision-chop forage harvester. One of the silages was ensiled on 4 June as direct-cut (dry matter (DM) content $153 \mathrm{~g} / \mathrm{kg}$ ) and the other four silages on 6 June simultaneously after a wilting period of $4 \mathrm{~h}$ (DM $204 \mathrm{~g} / \mathrm{kg})$. The additive treatment of the direct-cut silage was formic acid (FA) applied as AIV-II solution ( $800 \mathrm{~g} \mathrm{FA} / \mathrm{kg}+$ $20 \mathrm{~g}$ orthophosphoric acid $/ \mathrm{kg}$ ) at the rate of $4.5 \mathrm{l} / \mathrm{t}$. The treatments of the wilted silages were as follows: untreated, FA (4l/t), enzyme A (glucose oxidase (GO) + hemicellulase (HC) $150 \mathrm{ml} / \mathrm{t}+$ cellulase (C) $200 \mathrm{ml} / \mathrm{t}$ ), enzyme B (HC $150 \mathrm{ml} / \mathrm{t}+\mathrm{C} 200 \mathrm{ml} / \mathrm{t}$ ). C was produced by Trichoderma reesei, HC by Penicillium emersonii and GO by Aspergillus 
niger. The addition of $\mathrm{GO}$ was $50000 \mathrm{IU} / \mathrm{t}$ and the activity of C 25000 nkat (nanokatal) HEC (hydroxyethyl cellulose)/ml.

The enzyme solutions were delivered during the mowing of grass. FA was delivered by watering can during the filling of the $3 \mathrm{~m}^{3}$ pilot scale glass-fibre silos (ø $1.4 \mathrm{~m})$. After filling the silos were sealed with a plastic sheet, weighted $\left(400 \mathrm{~kg} / \mathrm{m}^{2}\right)$ and stored at ambient temperature. The temperature probes were placed in the middle of the silo for monitoring the temperature changes. The silos were opened after 5 months of storage.

Losses from the silo were measured by weighing and analyzing all the grass ensiled and the effluent and silage removed from the silo (in-out method), and by the buried bag method with 2 bags/silo (10 kg grass/bag) distributed throughout the silo.

\section{Experiment II}

A primary growth of fully emerged timothy (840 g/ kg) - red clover (Trifolium pratense) sward was harvested on 26 June. Silages were harvested as direct-cut (DM $199 \mathrm{~g} / \mathrm{kg}$ ) with a precision-chop forage harvester and ensiled simultaneously in the same pilot scale silos as in Exp. I. The treatments were as follows: untreated, FA applied as AIV-II (4 l/t) and GO (50 $000 \mathrm{IU} / \mathrm{t})$ applied at three levels of C as E200 $(200 \mathrm{ml} / \mathrm{t}), \mathrm{E} 400(400 \mathrm{ml} / \mathrm{t})$ and E800 $(800 \mathrm{ml} / \mathrm{t})$. Water was delivered to the untreated silage in an amount equal to that used to dilute enzyme solutions to achieve even distribution. The additives were delivered during the filling of the silos. Enzyme activities were the same as in Exp. I. The silos were sealed and weighted as in Exp. I and stored at ambient temperature for 2.5 months before the digestibility trial. Losses from the silo were measured with the in-out method as in Exp. I.

\section{Animals and experimental design}

Five mature male Finn sheep weighing $60-70 \mathrm{~kg}$ in Exp. I and $50-60 \mathrm{~kg}$ in Exp. II were placed in metabolism cages. The experi- ments were conducted as a $5 \times 5$ Latin square with $21 \mathrm{~d}$ periods. Each period consisted of a 10 day introduction with ad libitum feeding and a 4 day adaptation followed by a 7 day total collection of faeces and urine.

The silages were fed in two equal portions with $20 \mathrm{~g}$ of commercial mineral mixture daily. In addition, the animals had free access to water. The voluntary intake was measured during the days 5-10 of the ad libitum feeding period by offering the silages $100-150 \mathrm{~g}$ / $\mathrm{kg}$ in excess of the previous day's intake. During the collection period feeding was restricted to 50 and $45 \mathrm{~g} \mathrm{DM} / \mathrm{kg} \mathrm{W}^{0.75}$ in Exp. I and II, respectively.

\section{Sampling and chemical analyses}

Representative samples of grass were taken during the filling of the silos. As soon as the buried bags appeared from the silo, they were weighed and the content was sampled. Samples of silages, feed refusals, urine and faeces were taken in the digestibility experiments.

Silage DM content was determined by oven drying at $105^{\circ} \mathrm{C}$ for $24 \mathrm{~h}$ and corrected for the loss of the volatile substances (lactic acid, VFA, ammonia) according to PORTER et al. (1984). The fresh silage samples were analyzed for $\mathrm{pH}$, water soluble carbohydrates (WSC) according to Somogyı (1945) with modifications of SALO (1965), lactic acid (BARKER and Summerson 1941), volatile fatty acids (HuIDA 1973), ammonia nitrogen (N) (McCullough 1967), and soluble and total $\mathrm{N}$ by the Kjeldahl method. Effluent was analyzed for $\mathrm{pH}, \mathrm{DM}$, ash and total N. Fresh urine and faecal samples were analyzed for N. Feed analyses of grass, silages, refusals and faeces were made according to standard procedures. Neutral detergent fiber (NDF), acid detergent fiber (ADF) and acid detergent lignin (ADL) were determined in Exp. II according to GoERING and Van SoEst (1970). Hemicellulose was calculated as a difference between NDF and $\mathrm{ADF}$, and cellulose as a difference between ADF and ADL. The digestibility of the grass 
and silages in vitro was measured according to Tilley and Terry (1963).

\section{Statistical analyses}

The data from the digestibility trials were tested with analyses of variance for Latin squares (SNEDECOR and COCHRAN 1967) by using a model:

$$
\mathrm{y}_{\mathrm{ijkl}}=\mu+\mathrm{T}_{\mathrm{i}}+\mathrm{A}_{\mathrm{j}}+\mathrm{P}_{\mathrm{k}}+\mathrm{e}_{\mathrm{ijkl}}
$$

where T, A and P are the effects of treatment, animal and period, respectively. In Exp. II, the treatment effect was further partitioned to single degree of freedom by making comparisons of untreated vs additive treated silages, FA vs enzyme silages, E200 vs E800 (linear effect of enzyme level), and E400 vs E200 and E800 (quadratic effect of enzyme level).

\section{Results}

The chemical compositions of the grasses and the silages are given in Table 1. The activity of the enzymes was evidenced in both experiments by the lower crude fibre content of enzyme silages compared with untreated and FA silages. In Exp. II, the content of NDF and ADF decreased with the increasing level of enzyme application, the effect of enzymes being directed mainly towards cellulose. Also FA decreased the fibre content, mainly hemicellulose, but the effect was less evident than that of the enzymes.

After 5 days of storage, effluent $\mathrm{pH}$ was 3.2 (wilted) and 4.1 (unwilted) in FA and 4.2-4.3 in enzyme silages in Exp. I. No effluent formed from untreated silage. In Exp. II, the $\mathrm{pH}$ values of effluent were 4.3 in untreated, 4.1 in FA, and 4.2-4.3 in enzyme silages. The $\mathrm{pH}$ of the silages treated with additives declined near 4 with the exception of E200 ( $\mathrm{pH} 4.15)$. The untreated silages had a mean pH value of 4.4 and 4.8 in Exp. I and II, and a high content of acetic and propionic acid indicating both inadequate and secondary fermentation (Table 2). As compared with the enzymes the use of FA in both experiments resulted in more restricted fermentation, indicated by the lower lactic and acetic acid and higher residual WSC content in silage. In Exp. I, GO had no effect on the chemical composition or fermentation quality. In both experiments, enzyme treatment increased lac-

Table 1. Chemical compositions of the grasses and silages.

\begin{tabular}{|c|c|c|c|c|c|c|c|c|c|c|c|}
\hline & \multirow[b]{2}{*}{$\begin{array}{c}\text { DM } \\
(\mathrm{g} / \mathrm{kg})\end{array}$} & \multicolumn{10}{|c|}{ In dry matter ( $\mathrm{g} / \mathrm{kg} \mathrm{DM})$} \\
\hline & & Ash & $\begin{array}{c}\text { Crude } \\
\text { prot. }\end{array}$ & $\mathrm{EE}$ & $\begin{array}{l}\text { Crude } \\
\text { fibre }\end{array}$ & NFE & NDF & $\mathrm{ADF}$ & ADL & $\begin{array}{l}\text { Hemi- } \\
\text { cell. }\end{array}$ & $\begin{array}{c}\text { Cellu- } \\
\text { lose }\end{array}$ \\
\hline \multicolumn{12}{|l|}{ Experiment I } \\
\hline Unwilted grass & 153 & 91 & 195 & 44 & 270 & 401 & ND & ND & ND & & \\
\hline Formic acid & 180 & 82 & 186 & 57 & 291 & 387 & ND & ND & ND & & \\
\hline Wilted grass & 204 & 85 & 185 & 33 & 271 & 426 & ND & ND & ND & & \\
\hline Untreated & 222 & 89 & 180 & 53 & 290 & 389 & ND & ND & ND & & \\
\hline Formic acid & 219 & 83 & 178 & 49 & 286 & 403 & ND & ND & ND & & \\
\hline Enzyme A & 213 & 87 & 180 & 63 & 274 & 396 & ND & ND & ND & & \\
\hline Enzyme B & 214 & 84 & 182 & 67 & 271 & 396 & ND & ND & ND & & \\
\hline \multicolumn{12}{|l|}{ Experiment II } \\
\hline Unwilted grass & 199 & 67 & 127 & 30 & 344 & 433 & 635 & 336 & 17 & 299 & 319 \\
\hline Untreated & 190 & 74 & 131 & 40 & 401 & 355 & 666 & 377 & 20 & 289 & 358 \\
\hline Formic acid & 201 & 66 & 124 & 39 & 372 & 399 & 619 & 347 & 18 & 272 & 329 \\
\hline E200 & 207 & 67 & 128 & 48 & 361 & 396 & 609 & 341 & 20 & 268 & 320 \\
\hline $\mathrm{E} 400$ & 215 & 64 & 121 & 51 & 341 & 423 & 596 & 326 & 20 & 271 & 306 \\
\hline $\mathrm{E} 800$ & 216 & 64 & 122 & 51 & 356 & 408 & 579 & 315 & 21 & 265 & 294 \\
\hline
\end{tabular}

$\mathrm{EE}=$ ether extract, NFE = nitrogen free extract, $\mathrm{ND}=$ not determined 
tic acid concentration as compared with untreated silages. In Exp. II, the concentration of lactic acid and WSC increased with the level of enzyme application, whilst the concentration of acetic and propionic acid decreased. However, the total amount of acids was not increased by doubling the amount of enzyme from 400 to $800 \mathrm{ml} / \mathrm{t}$.
As compared with untreated silage the enzymes reduced proteolysis, the effect being most pronounced with the highest level of application. Least protein breakdown occurred, however, in the FA silages as indicated by the lowest ammonia-N content.

The use of FA and enzymes increased the formation of effluent (Table 3). The effect of

Table 2. Water soluble carbohydrate (WSC) and soluble $\mathrm{N}$ contents in the grass and the effect of additive treatment on the fermentation quality of silage.

\begin{tabular}{|c|c|c|c|c|c|c|c|c|c|c|}
\hline & \multirow[t]{2}{*}{$\mathrm{pH}$} & \multicolumn{6}{|c|}{ In dry matter (g/kg DM) } & \multirow{2}{*}{$\begin{array}{l}\text { Lactic } \\
\text { /acetic }\end{array}$} & \multicolumn{2}{|c|}{ In tot. $\mathrm{N}(\mathrm{g} / \mathrm{kg})$} \\
\hline & & WSC & $\begin{array}{c}\text { Lactic } \\
\text { acid }\end{array}$ & $\begin{array}{c}\text { Acetic } \\
\text { acid }\end{array}$ & $\begin{array}{l}\text { Prop. } \\
\text { acid }\end{array}$ & $\begin{array}{l}\text { But. } \\
\text { acid }\end{array}$ & $\begin{array}{l}\text { Total } \\
\text { acids }\end{array}$ & & $\mathrm{NH}_{3}-\mathrm{N}$ & $\begin{array}{c}\text { Solub. } \\
\mathrm{N}\end{array}$ \\
\hline \multicolumn{11}{|l|}{ Experiment I } \\
\hline Unwilted grass & & 57 & & & & & & & & 336 \\
\hline Formic acid & 4.06 & 15 & 63 & 18 & 0.8 & 0 & 82 & 3.5 & 63 & 605 \\
\hline Wilted grass & & 85 & & & & & & & & 325 \\
\hline Untreated & 4.40 & 2 & 93 & 30 & 0.7 & 0 & 124 & 3.1 & 113 & 704 \\
\hline Formic acid & 3.98 & 36 & 64 & 14 & 0 & 0 & 78 & 4.6 & 52 & 589 \\
\hline Enzyme A & 3.95 & 8 & 133 & 23 & 0 & 0 & 156 & 5.8 & 72 & 679 \\
\hline Enzyme B & 3.96 & 9 & 131 & 23 & 0 & 0 & 154 & 5.7 & 72 & 669 \\
\hline \multicolumn{11}{|l|}{ Experiment II } \\
\hline Unwilted grass & & 65 & & & & & & & & 419 \\
\hline Untreated & 4.81 & 1 & 8 & 61 & 12.8 & 0.1 & 81 & 0.1 & 148 & 736 \\
\hline Formic acid & 3.98 & 41 & 52 & 12 & 0.4 & 0 & 64 & 4.3 & 57 & 670 \\
\hline E200 & 4.15 & 5 & 92 & 34 & 4.1 & 0 & 130 & 2.7 & 119 & 720 \\
\hline $\mathrm{E} 400$ & 3.96 & 9 & 111 & 28 & 2.2 & 0 & 141 & 4.0 & 116 & 717 \\
\hline E800 & 3.93 & 17 & 111 & 20 & 0.9 & 0 & 132 & 5.6 & 87 & 676 \\
\hline
\end{tabular}

Table 3. In-silo dry matter $(\mathrm{DM})$ losses $(\mathrm{g} / \mathrm{kg})$ and the amount and DM content of effluent $(\mathrm{g} / \mathrm{kg})$ from the silages treated with different additives.

\begin{tabular}{|c|c|c|c|c|c|c|}
\hline & \multirow{2}{*}{$\begin{array}{c}\text { Effluent } \\
\text { losses }\end{array}$} & \multirow{2}{*}{$\begin{array}{l}\text { Other } \\
\text { losses }\end{array}$} & \multicolumn{2}{|c|}{ Total losses } & \multicolumn{2}{|c|}{ Effluent } \\
\hline & & & In-out & Bags & $\mathrm{kg} / \mathrm{t}$ grass $^{1}$ & DM content \\
\hline \multicolumn{7}{|l|}{ Experiment I } \\
\hline $\begin{array}{l}\text { Unwilt. formic acid } \\
\text { Wilted }\end{array}$ & 46 & 92 & 138 & 110 & 140.0 & 46 \\
\hline Untreated & 0 & 37 & 37 & 47 & 0 & - \\
\hline Formic acid & 8 & 50 & 58 & 44 & 5.6 & 62 \\
\hline Enzyme A & .17 & 88 & 105 & 67 & 27.2 & 69 \\
\hline Enzyme B & 23 & 37 & 60 & 45 & 46.0 & 72 \\
\hline \multicolumn{7}{|l|}{ Experiment II } \\
\hline Untreated & 3 & 114 & 117 & & 0 & 48 \\
\hline Formic acid & 7 & 89 & 96 & & 0 & 56 \\
\hline E200 & 21 & 99 & 120 & & 40.3 & 61 \\
\hline E400 & 40 & 67 & 107 & & 94.2 & 65 \\
\hline E800 & 49 & 72 & 121 & & 107.8 & 71 \\
\hline
\end{tabular}

I The amount of additive and water delivered subtracted 
enzymes was more profound than that of FA, and it increased with the level of enzyme application. The methods of measuring total losses were highly correlated $(r=0.93)$ ranking the silages in a similar manner with highest losses in the unwilted FA silage. The temper- ature of silages at ensiling ranged from 17 to $20^{\circ} \mathrm{C}$ and the maximum temperature (20$25^{\circ} \mathrm{C}$ ) was reached 7 days after ensiling, being highest with the untreated silages. The increase was $2^{\circ} \mathrm{C}$ smaller in the FA silages when compared with the enzyme silages.

Table 4. Digestibility coefficients, voluntary silage DM intake and nitrogen balance in sheep and in vitro digestibility of silage and grass organic matter (OM) in Exp. I.

\begin{tabular}{|c|c|c|c|c|c|c|}
\hline & \multirow{2}{*}{$\begin{array}{c}\text { Unwilted } \\
\begin{array}{c}\text { Formic } \\
\text { acid }\end{array}\end{array}$} & \multicolumn{4}{|c|}{ Wilted } & \multirow[t]{2}{*}{ SEM } \\
\hline & & Untreated & $\begin{array}{c}\text { Formic- } \\
\text { acid }\end{array}$ & Enzyme A & Enzyme B & \\
\hline Dry matter & 0.744 & 0.746 & 0.750 & 0.757 & 0.759 & 0.0039 \\
\hline Organic matter & 0.762 & 0.758 & 0.765 & 0.771 & 0.772 & 0.0043 \\
\hline Crude protein & 0.769 & 0.767 & 0.778 & 0.781 & 0.783 & 0.0042 \\
\hline Ether extract & $0.740^{\mathrm{ae}}$ & $0.746^{\text {ade }}$ & $0.715^{\text {ae }}$ & $0.794^{\text {bed }}$ & $0.803^{\text {bc }}$ & 0.0088 \\
\hline Crude fibre & 0.777 & 0.784 & 0.779 & 0.771 & 0.775 & 0.0085 \\
\hline $\mathrm{N}$-free extract & $0.743^{\mathrm{ab}}$ & $0.729^{b}$ & $0.751^{\mathrm{ab}}$ & $0.753^{a}$ & $0.751^{\mathrm{a}}$ & 0.0048 \\
\hline \multicolumn{7}{|l|}{ Digest. in vitro } \\
\hline Silage OM & 0.734 & 0.729 & 0.736 & 0.747 & 0.746 & \\
\hline Grass OM & 0.737 & 0.726 & 0.726 & 0.714 & 0.727 & \\
\hline \multicolumn{7}{|l|}{ Silage DM intake } \\
\hline$\left(\mathrm{g} / \mathrm{d} / \mathrm{kg} \mathrm{W}^{0.75}\right)$ & 52.4 & 57.2 & 55.7 & 53.9 & 57.9 & 3.97 \\
\hline $\mathrm{N}$ retained $(\mathrm{g} / \mathrm{d})$ & 2.5 & 1.4 & 2.9 & 2.0 & 2.9 & 0.59 \\
\hline
\end{tabular}

SEM = standard error of means

Means with different letters were significantly different: $a, b(P<0.05), c, d, e(P<0.01)$.

Table 5. Digestibility coefficients, voluntary silage DM intake and nitrogen balance in sheep and in vitro digestibility of silage and grass organic matter (OM) in Exp. II.

\begin{tabular}{|c|c|c|c|c|c|c|c|c|c|c|}
\hline & \multirow[t]{2}{*}{$\begin{array}{c}\text { Un- } \\
\text { treated }\end{array}$} & \multirow[t]{2}{*}{$\begin{array}{l}\text { Formic } \\
\text { acid }\end{array}$} & \multirow[t]{2}{*}{ E200 } & \multirow[t]{2}{*}{$\mathrm{E} 400$} & \multirow[t]{2}{*}{ E800 } & \multirow[t]{2}{*}{ SEM } & \multicolumn{4}{|c|}{$\begin{array}{c}\text { Statistical significance } \\
\text { of effect }\end{array}$} \\
\hline & & & & & & & $\mathrm{Cl}$ & $\mathrm{C} 2$ & $\mathrm{C} 3$ & $\mathrm{C} 4$ \\
\hline Dry matter & 0.676 & 0.678 & 0.674 & 0.669 & 0.640 & 0.0084 & NS & NS & $*$ & NS \\
\hline Organic matter & 0.678 & 0.683 & 0.677 & 0.675 & 0.644 & 0.0083 & NS & NS & $*$ & NS \\
\hline Crude protein & 0.727 & 0.687 & 0.729 & 0.703 & 0.676 & 0.0087 & NS & NS & $* *$ & NS \\
\hline Ether extract & 0.723 & 0.717 & 0.765 & 0.791 & 0.758 & 0.0083 & $* *$ & $* * *$ & NS & $*$ \\
\hline Crude fibre & 0.728 & 0.714 & 0.685 & 0.661 & 0.656 & 0.0119 & $* *$ & $* *$ & NS & NS \\
\hline $\mathrm{N}$-free extract & 0.599 & 0.646 & 0.641 & 0.662 & 0.609 & 0.0104 & $* *$ & NS & NS & $*$ \\
\hline NDF & 0.707 & 0.695 & 0.672 & 0.666 & 0.619 & 0.0106 & $* *$ & $* *$ & $* *$ & NS \\
\hline ADF & 0.734 & 0.716 & 0.697 & 0.684 & 0.639 & 0.0106 & $* *$ & $* *$ & $* *$ & NS \\
\hline Hemicellulose & 0.672 & 0.667 & 0.641 & 0.645 & 0.595 & 0.0113 & $*$ & $* *$ & $*$ & NS \\
\hline Cellulose & 0.777 & 0.762 & 0.740 & 0.733 & 0.692 & 0.0115 & $* *$ & $*$ & $*$ & NS \\
\hline \multicolumn{11}{|l|}{ Digest. in vitro } \\
\hline Silage OM & 0.635 & 0.671 & 0.657 & 0.642 & 0.638 & & & & & \\
\hline Grass OM & 0.689 & 0.689 & 0.689 & 0.689 & 0.689 & & & & & \\
\hline \multicolumn{11}{|l|}{ Silage DM intake } \\
\hline$\left(\mathrm{g} / \mathrm{d} / \mathrm{kg} \mathrm{W}^{0.75}\right)$ & 41.6 & 52.6 & 55.1 & 51.3 & 56.4 & 2.53 & $* * *$ & NS & NS & NS \\
\hline $\mathrm{N}$ retained $(\mathrm{g} / \mathrm{d})$ & 2.0 & 1.8 & 2.2 & 2.4 & 2.7 & 0.42 & NS & NS & NS & NS \\
\hline
\end{tabular}

Comparisons: $\mathrm{C} 1=$ untreated vs additives, C2 $=$ FA vs enzymes, C3 = linear effect of enzyme level, C4 = quadratic effect of enzyme level

Statistical significance: NS not significant, ${ }^{*}(\mathrm{P}<0.05),{ }^{* *}(\mathrm{P}<0.01),{ }^{* * *}(\mathrm{P}<0.001)$ 
Results concerning the digestion of different feed constituents in Exp. I are given in Table 4. No significant $(P>0.05)$ differences were observed in the digestibility of DM, organic matter (OM), crude protein and crude fibre. The digestibility of the nitrogen free extract (NFE) of the enzyme silages was significantly $(\mathrm{P}<0.05)$ higher than that of the untreated silage. The significant $(\mathrm{P}<0.05$, $\mathrm{P}<0.01)$ differences in the digestibility of ether extract were mainly caused by the high concentrations of fermentation acids in the enzyme silages and are of minor importance.

In Exp. II, no significant differences were noticed in DM, OM and crude protein digestibility between untreated and other or FA and enzyme silages (Table 5). However, the corresponding digestibilities decreased $(\mathrm{P}<0.05$, $\mathrm{P}<0.01$ ) with the increasing level of enzyme application. The use of additives (FA and enzymes) increased significantly $(\mathrm{P}<0.01)$ the digestibility of ether extract and NFE, and decreased that of crude fibre, NDF, ADF, cellulose $(\mathrm{P}<0.01)$ and hemicellulose $(\mathrm{P}<0.05)$.

As compared with FA, the use of enzymes decreased $(\mathrm{P}<0.05, \mathrm{P}<0.01)$ the digestibility of all fibre fractions. Moreover, an increase in the enzyme level decreased linearly $(\mathrm{P}<0.05$, $\mathrm{P}<0.01)$ the digestibility of cell wall carbohydrates. In Exp. I, there were no differences in the voluntary silage DM intake between the silages (Table 4) whereas in Exp. II the untreated silage was consumed significantly $(\mathrm{P}<0.001)$ less than the other silages $(\mathrm{Ta}-$ ble 5). No differences were observed in $\mathrm{N}$ retention between the silages.

\section{Discussion}

\section{Plant cell wall degradation}

As compared with the untreated silage the content of crude fibre in enzyme silages decreased $16-19$ and $40-60 \mathrm{~g} / \mathrm{kg}$ DM in Exp. I and II, respectively, indicating mainly the breakdown of cellulose because a major part of hemicellulose is lost in the crude fibre analysis. Exp. II confirmed this, since the cellulose content decreased $38-64 \mathrm{~g} / \mathrm{kg}$ DM with the increasing enzyme level. The results are in good agreement with those of RAURAMAA et al. (1987 a). The cell wall degrading effect appears to be evident in most experiments with fibrinolytic enzymes (AUTREY et al. 1975, McCullough 1964, McHan 1986, HeIKKILÃ et al. 1987), while the material ensiled, enzyme activities and amount applied cause variation in the intensity of enzyme effects.

The decreasing of the NDF and ADF content with increasing enzyme level is consistent with other experiments, where the amount of fermentable carbohydrates released has been proportional to the amount of enzymes applied (Henderson and McDonald 1977, VAISTO et al. 1978, NeHring et al. 1983, BroLLY 1986). Hissa (1986) studied the effects of the increasing level of enzyme application up to 4 times greater level than E800. It was concluded that the degradation of cellulose followed the formula $y=a-b\left(1-e^{-c x}\right)$, in which $\mathrm{a}, \mathrm{b}$ and $\mathrm{c}$ are constants and $\mathrm{x}$ is the level of cellulase. According to that the maximal degradation of NDF could have been $75 \mathrm{~g} /$ $\mathrm{kg}$ DM. On the other hand, HENDERSSON and McDonald (1977) suggest that the end product inhibition may allow hydrolysis of no more than $300-400 \mathrm{~g}$ cellulose/ $\mathrm{kg}$ cellulose ensiled.

Microbes, plant enzymes, acid additives or acids formed during fermentation may also decrease the cell wall content of silage. In Exp. II, the content of hemicellulose decreased more in FA $(90 \mathrm{~g} / \mathrm{kg})$ than in untreated silage $(33 \mathrm{~g} / \mathrm{kg})$. Consistently, FA degraded mainly hemicellulose, which could loose up to $200 \mathrm{~g}$ / $\mathrm{kg}$ of its content in ryegrass (MORRISON 1979). On the other hand, DM losses in the form of $\mathrm{CO}_{2}$ and effluent causes an increase in the fibre content of silage. The reverse effects of the losses and the above mentioned factors tend to offset each other.

\section{The fermentation quality of the silages}

The importance of the WSC content, buffering capacity and DM content of the grass 
for preservation without additives is well defined (McDonald 1981). In the present study the WSC content of grass was 17 and $13 \mathrm{~g} / \mathrm{kg}$ fresh weight. The quality of untreated silages obviously reflected the WSC contents being in agreement with the suggestions that WSC content of fresh grass should be at least 25$30 \mathrm{~g} / \mathrm{kg}$ to achieve satisfactory preservation (Wilkinson et al. 1983, Pettersson 1988). The amount of WSC + total acids exceeded $30 \mathrm{~g} / \mathrm{kg}$ in the enzyme silages, except for E200 $(28 \mathrm{~g} / \mathrm{kg})$, but not in untreated silages ( 28 and $16 \mathrm{~g} / \mathrm{kg}$ ). These values are in agreement with the differences in fermentation quality between untreated and enzyme silages, indicating that the fermentable substrates released by enzymes accomplished the preservation. On the other hand, with grass of higher WSC content, no differences were observed in fermentation quality between untreated and enzyme silages (RAuramaA et al. 1987 a, TOIVONEN 1989).

Low WSC content $(<20 \mathrm{~g} / \mathrm{kg}$ DM) in all enzyme silages indicated that sugars released from cell wall were fermented to acids. As compared with untreated silage the amount of lactic acid was much higher in enzyme treated silage, facilitating the achievement of low $\mathrm{pH}$. The final $\mathrm{pH}$ was the same as in FA silages with the exception of E200 in Exp. II. The same positive effect of enzymes has been found also in other experiments (AUTREY et al. 1975, Henderson and McDonald 1977, Nehring et al. 1983, Hendersson et al. 1987, Merry and Braithwaite 1987). Applied in conjunction with FA, enzymes may have no effect on the conversion of WSC to fermentation acids and thus on $\mathrm{pH}$ (HENDERSON and McDonald 1977, Vaisto et al. 1978, Brolly 1986).

Measured from effluent the decrease in the $\mathrm{pH}$ in the first days was not more rapid in enzyme than in untreated silages. After the first weeks, however, the enzymes proved to be efficient in decreasing $\mathrm{pH}$ further. In untreated silages, the lack of fermentable substrates later led to increased $\mathrm{pH}$ due to secondary fermentation. With grass rich in WSC, ensiled with- out additive or with cellulase, the $\mathrm{pH} 4$ was obtained after vigorous fermentation within one week (RAuramaA et al. 1987 a). As compared with direct acidification with FA, the natural fermentation does not reduce silage $\mathrm{pH}$ equally rapidly in the first hours of ensiling. This is obviously the main reason for the lower ammonia $\mathrm{N}$ contents in the FA silages as compared with enzyme treated and especially with untreated silages. The better inhibitory effect of FA on proteolysis as compared with enzymes agrees with the results from other experiments (KENNEDy 1987, RaURAMAA et al. 1987 a).

While containing the same total amount of acids, there was a clear difference in the $\mathrm{pH}$ values between E200 and E800 (4.15 vs 3.93), indicating different strength of lactic $\left(\mathrm{pK}_{\mathrm{a}}\right.$ 3.8) and acetic acids $\left(\mathrm{pK}_{\mathrm{a}} 4.8\right)$. Generally, the increase in the lactic acid/acetic acid $(\mathrm{L} / \mathrm{A})$ ratio is mainly an indication of a more homolactic fermentation or different fermentable substrates. Due to the breakdown of cell walls, xylose and arabinose are released from the hemicellulose fraction, while glucose is released from cellulose. Some lactic acid bacteria are able to ferment pentose sugars to a mixture of lactic and acetic acids, homo- and heterofermentative bacteria having the same pathways (McDonald 1981). The lower L/A ratio in the FA silages than in both enzyme silages in Exp. I and in E800 in Exp. II might suggest that proportionally more glucose was released by enzyme than FA treatment rather than indicate differences in microbial population. This is supported by the results of RAURAmAa et al. (1987 b), who found that despite of the lower L/A ratio in FA silage (2.4) than in cellulase treated silage (4.1), the number of homofermentative lactic acid bacteria was greater in the FA silage. The original hexose sugars in acid treated silage may partially be lost in effluent due to the high level of acid application (HENDERSON and McDonald 1971). Low L/A ratio in E200 and untreated silage reflects rather fermentation of lactic acid to acetic acid (WoOLFORD 1984, LiNDGREN et al. 1987), degradation of 
amino acids to acetic acid, or more heterolactic fermentation (McDonald 1981) than variation in fermentable substrate. The presence of acetic acid may also indicate the action of saccharolytic clostridia or enterobacteria (WoOlford 1984). Even with grass rich in WSC, the silage produced with cellulolytic enzymes had a higher L/A ratio than wellpreserved untreated silage (RAURAMAA et al. 1987 b).

The positive effect of increased enzyme application on the quality of silage has also been reported by LEATHERWOOD et al. (1963) and Autrey et al. (1975). When the level of cellulase increased from 0.3 to $0.9 \mathrm{~g} / \mathrm{kg}$ lucerne, the $\mathrm{pH}$ decreased more quickly with higher lactic acid and lower ammonia $\mathrm{N}$ content (Hendersson et al. 1987). Hissa (1986) found increased soluble $\mathrm{N}$ content with increasing level of cellulase in laboratory silos probably due to the breakdown of cell walls and subsequent release of cell contents. However, ammonia $\mathrm{N}$ and true protein content were not affected by the level of cellulase. Increasing the level of enzyme application increased the content of lactic acid; however, with E800 the effect was obviously offset by higher losses of acids in the effluent. At the same time the L/A ratio increased giving no support to the suggestion of RAURAMAA et al. (1987 b), that when lactic acid content exceeds $80-100 \mathrm{~g} / \mathrm{kg}$ DM there may occur inhibition of the end product, resulting in a change in the bacterial population or its metabolism so that relatively more acetic acid is produced.

Glucose oxidase (GO) converts free glucose into gluconic acid $\left(\mathrm{pK}_{\mathrm{a}} 3.76\right)$, reduces $\mathrm{pH}$ and consumes oxygen (HEIKONEN et al. 1987). No differences were observed in the fermentation parameters of enzyme silages in Exp. I, perhaps due to the low content of WSC in grass and the low rate of application of GO. The same was noticed also by Hissa (1986). The effect of GO on oxygen consumption was not measured. The maximum temperature was slightly lower in FA silages, indicating inhibiting effect of FA on respiratory enzymes. In laboratory conditions, in a well-sealed, well- compacted silage, anaerobiosis is achieved as rapidly as in $30 \mathrm{~min}$ (SPrague 1974, WoolFORD 1984).

\section{In-silo losses}

In agreement with the results of Brolly (1986) and JACOBS and McAllan (1987) enzymes increased effluent losses as compared with FA and especially untreated silage. LEATHERWOOD et al. (1963) and VAisto et al. (1978) observed higher amounts of free water in enzyme than in untreated silages. In contrast, no increase in the volume of effluent with enzymes was found by Brolly (1986) with lucerne and KENNEDY (1987) with grass silage. Likewise enzyme treatment, FA releases cell sap by penetrating beyond the epicuticular layer into the tissue and by disrupting mesophyll cell membranes (WINTERS et al. 1987). The reaction is beneficial for rapid fermentation but leads to increased effluent formation with high moisture grasses (PEDERSEN et al. 1973; BASTIMAN 1976).

\section{Digestibility of the silages}

The use of additives had no significant effect on the digestibility of OM, which is in agreement with the results from other studies with FA and enzyme silage in steers (JACOBS and McAlLAN 1987) or in sheep (BROlly 1986). E800 silage showed no evidence of secondary fermentation or aerobic deterioration, and the DM losses due to homoand heterolactic fermentation are negligible (McDonald 1981). The decreased OM digestibility of E800 might have been caused by greater effluent losses. Consequently, under the conditions of experiment II, increasing the level of enzyme application improved fermentation quality while increasing effluent losses and decreasing OM digestibility. This suggests that no cut-off mechanism was present to stop enzyme activity, which should be a criteria for a good enzyme system (SEAle 1987).

The use of enzymes clearly reduced the digestibility of fibre in Exp. II, indicating a 
change in the composition of the fibre fraction during ensiling. The linear decrease in the NDF and ADF digestibilities with increasing level of enzyme application suggests that the enzymes degraded the most easily digestible cell wall fraction and the remaining NDF and ADF were proportionally less digestible. The same tendency towards lower fibre digestibility has been noticed also by Brolly (1986) and HeIKKILÄ et al. (1987). Consistent with that, the disappearance of silage from nylon bags over long incubation times in the rumen showed no improvement in the potential digestibility (Hissa 1986, van VUUREN et al.
1989). Obviously the enzymes were not able to degrade the ligninpolysaccharide complexes of plant cell walls, which are indigestible by rumen microbes.

In conclusion, the use of enzymes as additive improved the fermentation quality of grass silage as compared with untreated silage. The present results suggest that because the digestibility of OM cannot be improved by increasing the level of enzyme application, the optimal level of cellulase with low DM silage is the lowest possible ensuring satisfactory preservation.

\section{References}

Autrey, K.M., McCaskey, T.A. \& Little, J.A. 1975. Cellulose digestibility of fibrous materials treated with Trichoderma viride cellulase. J. Dairy Sci. 58: 67-71.

Barker, S.B. \& Summerson, W.H. 1941. The colorimetric determination of lactic acid in biological material. J. Biol. Chem. 138: 535-554.

Bastiman, B. 1976. Factors affecting silage effluent production. Exp. Husb. 31: 40-46.

Brolly, R.G. 1986. The effect of in-silo addition of cellulases and hemicellulases on the chemical composition and nutritional value of silage. A thesis for the degree of Master of Science in the Faculty of Science, University of Glasgow. $146 \mathrm{p}$.

Done, D.L. 1986. Silage inoculants - A review of experimental work. Research and Development in Agriculture 2: 83-87.

Goering, H.R. \& van Soest, P.J. 1970. Forage fibre analyses. Agriculture Handbook No. 379. United States Department of Agriculture. Washington.

HeikKilä, T., VăÄtÄInen, H. \& Lampila, M. 1987. Erilaiset nurmirehut lypsylehmien ruokinnassa. Suomen maataloustieteellisen seuran tiedote 9: 43-54.

Heikonen, M., Moisio, T. \& Harju, M. 1987. Composition and method for ensilaging fodder and grain. European patent specification, number 0108568 .

Henderson, A.R. \& McDonald, P. 1971. Effect of formic acid on the fermentation of grass of low dry matter content. J. Sci. Food Agric. 22: 157-163.

- \& McDonald, P. 1977. The effect of cellulase preparations on the chemical changes during the ensilage of grass in laboratory silos. J. Sci. Food Agric. 28: 486-490.

-, McDonald, P. \& Anderson, D. 1982. The effect of cellulase preparation derived from Trichoderma viride on the chemical changes during ensilage of grass, lucerne and clover. J. Sci. Food Agric. 33: 16-20.
- \& McGinn, R. and KerR, W.D. 1987. The effect of a cellulase preparation applied with or without an inoculum of lactic acid bacteria on the chemical composition of lucerne ensiled in laboratory silos. Eight Silage Conference. AFRC, IGAP, Hurley, pp. 29-30.

HıssA, K. 1986. Entsyymit nurmirehun săilönnăssă. Helsingin yliopisto, kotielăintieteen laitos. Pro gradu -tyō. $99 \mathrm{~s}$.

Huhtanen, P., Hissa, K., Jaakkola, S. \& Poutiainen, E. 1985. Enzymes as silage additives. Effect in fermentation quality, digestibility in sheep, degradability in sacco and performance in growing cattle. J. Agric. Sci. Finl. 57: 284-292.

Huida, L. 1973. Quantitative determination of volatile fatty acids from rumen sample and silage by gasliquid chromatography. J. Sci. Agric. Soc. Finl. 45: 438-488.

JacoBs, J.L. \& McAllan, A.B. 1987. Enzyme additives for silage. Digestibilities and nitrogen retention in growing steers. Eight Silage Conference. AFRC, IGAP, Hurley, pp. 107-108.

JASTER, E.H. \& MOORE, K.J. 1988. Fermentation characteristics and feeding value of enzyme-treated alfalfa haylage. J. Dairy Sci. 71: 705-711.

KENNEDY, S.J. 1987. The effect of an enzyme additive on the preservation and nutritive value of grass fed to beef cattle. Eight Silage Conference. AFRC, IGAP, Hurley, pp. 25-26.

Leatherwood, J.M., Mochrie, R.D., Stone, E.J. \& Tномаs, W.E. 1963. Cellulose degradation by enzymes added to ensiled forages. J. Dairy Sci. 46: $124-127$.

Lindgren, S., Lingyall, P. \& Pettersson, K. 1987. Relation between chemical quality and microbial composition in silages. Eight Silage Conference. AFRC, 
IGAP, Hurley. pp. 11-12.

Merry, R.J. \& Braithwaite, G.D. 1987. The effect of enzymes and inoculants on the chemical and microbiological composition of grass and legume silages. Eight Silage Conference. AFRC, IGAP, Hurley, pp. $27-28$.

Morrison, I.M. 1979. Changes in the cell wall components of laboratory silages and the effect of various additives on these changes. J. Agric. Sci., Camb. 93: 581-586.

McCulıough, M.E. 1964. Influence of cellulase on silage fermentation. J. Dairy Sci. 47: 342 (Abstr.).

- 1967. The determination of ammonia in whole blood by direct colorimetric method. Clin. Chim. Acta 17: 297-304.

McDonald, P. 1981. The biochemistry of silage. John Wiley and Sons, $226 \mathrm{p}$.

McHAN, F. 1986. Cellulase-treated coastal bermudagrass silage and production of soluble carbohydrates, silage acids, and digestibility. J. Dairy Sci. 69: 431-438.

Nehring, K., Heinz, D. \& Friedel, K. 1983. Der Einfluss von Zellulase auf die Silierung von eiweissreichen Futterstoffen. Arch. Tierernhr. 33: 251-258.

Olson, M. \& Voelker, H.H. 1961. Effectiveness of enzyme and culture additions on the preservation and feeding value of alfalfa silage. J. Dairy Sci. 44: 1204 (Abstr.)

OWEN, F.G. 1962. Effect of enzymes and bacitracin on silage quality. J. Dairy Sci. 45: 934-936.

Pedersen, T.A., Olsen, R.A. \& Guttormsen, D.M. 1973. Numbers and types of microorganisms in silage and effluent from grass ensiled with different additives. Acta Agric. Scand. 23: 109-120.

Pettersson, K. 1988. Ensiling of forages. Factors affecting silage fermentation and quality. Swedish Univ. Agric. Sci., Dept. Anim. Nutr. Managem., Rapport 179, Uppsala (Diss.)

Porter, M.G., Patterson, D.C., Steen, R.W.J. \& GorDON, F.J. 1984. Determination of dry matter and gross energy of grass silage. Seventh silage conference. Summary of Papers. p. 8. The Queens University of Belfast.

Rauramaa, A., Setãlā, J., Moisıo, T., Heikkilä, T. \& LAMPILA, M. 1987 a. The effect of inoculants and cellulase on the fermentation and microbiological composition of grass silage. I Biochemical changes in the silages. J. Agric. Sci. Finl. 59: 361-370.

—, Setãlā, J., Moisıo, T., Sivelä, S., Heikkilä, T. \& LAMPILA, M. 1987 b. The effect of inoculants and cellulase on the fermentation and microbiological composition of grass silage. II Microbiological changes in the silages. J. Agric. Sci. Finl. 59: 371-377.

SALo, M-L. 1965. Determination of carbohydrate fractions in animal foods and faeces. Acta Agr. Fenn. 105: 1-102.
Saue, O. \& Breirem, K. 1969. Formic acid as a silage additive. Proc. 3rd Gen. Meet. Eur. Grassl. Fed., Braunschweig, pp. 161-172.

Seale, D.R. 1987. Bacteria and enzymes as products to improve silage preservation. In: Developments in silage (ed. Wilkinson, J.M. \& Stark, B.A.), Chalcombe Publ. pp. $47-61$.

-, Henderson, A.R., Petterson, K.O. \& Lowe, J.F. 1986. The effect of addition of sugar and inoculation with two commercial inoculations on the fermentation of lucerne silage in laboratory silos. Grass and Forage Sci. 41: 61-70.

Snedecor, G.W. \& Cochran, W.G. 1967. Statistical methods. 6th ed. Ames, Iowa. 593 p.

Somogyı, M. 1945. A new reagent for the determination of sugars. J. Biol. Chem. 160; 61-68.

Sprague, M.A. 1974. Oxygen disappearance in alfalfa silage (Medicago sativa, L). Sectional paper, 12th Int. Grassld. Congr., pp. 216-225.

Tilley, J.M.A. \& Terry, R.A. 1963. A two-stage technique for in vitro digestion of forage crops. $\mathrm{J}$. $\mathrm{Br}$. Grassl. Soc. 18: 104-111.

Tolvonen, V. 1989. Additives and the quality of silage. International Symposium on Production, Evaluation and Feeding of silage, 1989, Rostock, GDR.

Vaisto, T., Heikonen, M. \& Kreula, M. 1978. The use of cellulases for increasing the sugar content of AIVsilage. J. Scient. Agric. Soc. Finl. 50: 392-397.

van Vuuren, A.M., Bergsma, K., Frol-Kramer, F. \& van BeERS, J.A.C. 1989. Effects of addition of cell wall degrading enzymes on the chemical composition and the in sacco degradation of grass silage. Grass and Forage Sci. 44: 223-230.

Wilkinson, J.M., Chapman, P.F., Wilkins, R.J. \& WILSON, R.F. 1983. Inter-relationships between pattern of fermentation during ensilage and initial crop composition. Proc. 14th Int. Grassld Congr., Lexington, pp. $631-634$.

WILSON, R.F. \& WILKINS, R.J. 1973. Formic acid as a silage additive for wet crops of cocksfoot and lucerne. J. Agric. Sci., Camb. 80: 225-231.

Winters, A.L., Whittaker, P.A. \& Wilson, R.K. 1987. Microscopic and chemical changes during the first 22 days in Italian ryegrass and cocksfoot silages made in laboratory silos. Grass and Forage Science 42: 191-196.

WoOlford, M.K. 1975. Microbiological screening of the straight chain fatty acids $(\mathrm{C} 1-\mathrm{C} 12)$ as potential silage additives. J. Sci. Food Agric. 26: 219-228.

- 1984. The silage fermentation. New York, Marcel Dekker Inc., 350 p.

Ms received November 10, 1990 


\section{Kuitua hajottavien entsyymien vaikutus nurmirehun säilyvyyteen ja syöntiin sekä sulavuuteen lampaalla}

\section{Seija Jaakkola}

Helsingin yliopisto, kotieläintieteen laitos, $00710 \mathrm{Helsinki}$

Kahdessa kokeessa tutkittiin kasvin soluseinămiä hajottavien entsyymien kăyttőă nurmirehun săilöntäaineena. Kokeessa I timoteinurmen ensimmäinen sato niitettiin aikaisella kasvuasteella ja korjattiin tarkkuussilppurilla. Kokeessa II korjuu tehtiin myöhăisellă kasvuasteella suoraan tarkkuussilppurilla. Säilöntäainekäsittelyt olivat kokeessa I: 1) muurahaishappo (MH) AIV-2 liuoksena $4.5 \mathrm{l} / \mathrm{t}, 2$ ) painorehu (ei käsittelyä), 3) $\mathrm{MH} 4 \mathrm{l} / \mathrm{t}$, 4) entsyymi A (glukoosioksidaasi (GO) + hemisellulaasi (HS) $150 \mathrm{ml} / \mathrm{t}+$ sellulaasi (S) $200 \mathrm{ml} / \mathrm{t}$ ), 5) entsyymi B (HS $150 \mathrm{ml} / \mathrm{t}+\mathrm{S} 200 \mathrm{ml} / \mathrm{t}$ ). Rehu 1 korjattiin tuoreena ja rehut $2-5$ esikuivattuna. Kokeen II käsittelyt olivat: 1) painorehu, 2) $\mathrm{MH} 4 \mathrm{l} / \mathrm{t}, 3) \mathrm{E} 200(\mathrm{~S} 200 \mathrm{ml} / \mathrm{t}+\mathrm{GO}$ ), 4) $\mathrm{E} 400(\mathrm{~S} 400 \mathrm{ml} / \mathrm{t}+\mathrm{GO}), 5) \mathrm{E} 800(\mathrm{~S} 800 \mathrm{ml} / \mathrm{t}+\mathrm{GO})$. GO:n annostus oli $50000 \mathrm{IU} / \mathrm{ml}$. Rehut tehtiin $3 \mathrm{~m}^{3}: \mathrm{n}$ pilotsiiloihin. Vapaaehtoinen syönti ja sulavuus mäăritettiin lampailla kahdessa $5 \times 5$ latinalaisen neliön mukaisessa kokeessa.

Entsyymien kăyttő alensi săilörehun kuitupitoisuutta
MH- ja painorehuun verrattuna. Entsyymirehujen săilönnăllinen laatu oli hyvă $\mathrm{pH}$ :n vaihdellessa 3.93 ja 4.15 vălillă sekä ammoniakkitypen $72-119 \mathrm{~g} / \mathrm{kg}$ kok. N. Rehuissa ei ollut voihappoa. Painorehujen laatu oli selvästi entsyymirehuja heikompi ( $\mathrm{pH} 4.6$, ammoniakkityppi $133 \mathrm{~g} / \mathrm{kg}$ kok. N). MH-rehut olivat hyvin säilyneitä fermentaation ollessa selvästi vähäisempaaả kuin entsyymirehuissa. Sekă $\mathrm{MH}$ ettă korkeimmat entsyymimäärăt lisäsivăt puristenesteen muodostumista. Kokeessa I săilöntäaineet eivăt vaikuttaneet $(\mathrm{P}>0.05)$ kuiva-aineen (KA), orgaanisen aineen (OA) tai raakakuidun sulavuuteen. Kokeessa II entsyymien annostustason nosto huononsi lineaarisesti $(\mathrm{P}<0,01) \mathrm{KA}$ :n ja OA:n sulavuuksia. NDF:n ja ADF:n sulavuudet olivat paremmat painorehussa kuin käsitellyissä rehuissa, paremmat $\mathrm{MH}$ rehussa kuin entsyymirehuissa ja huononivat lineaarisesti entsyymitason noustessa $(\mathrm{P}<0.01)$. Entsyymirehujen sulavuus oli kuitenkin selvästi huonompi vain kăytettãessă korkeimpia entsyymitasoja. 